\title{
Proteome Analysis of Pyloric Ceca: A Methodology for Fish Feed Development?
}

\author{
Wulff, Tune; Petersen, Jørgen; Nørrelykke, Mette R.; Jessen, Flemming; Nielsen, Henrik H.
}

Published in:

Journal of Agricultural and Food Chemistry

Link to article, DOI:

$10.1021 / \mathrm{j} f 3016943$

Publication date:

2012

Document Version

Publisher's PDF, also known as Version of record

Link back to DTU Orbit

Citation (APA):

Wulff, T., Petersen, J., Nørrelykke, M. R., Jessen, F., \& Nielsen, H. H. (2012). Proteome Analysis of Pyloric Ceca: A Methodology for Fish Feed Development? Journal of Agricultural and Food Chemistry, 60(34), 84578464. https://doi.org/10.1021/jf3016943

\section{General rights}

Copyright and moral rights for the publications made accessible in the public portal are retained by the authors and/or other copyright owners and it is a condition of accessing publications that users recognise and abide by the legal requirements associated with these rights.

- Users may download and print one copy of any publication from the public portal for the purpose of private study or research.

- You may not further distribute the material or use it for any profit-making activity or commercial gain

- You may freely distribute the URL identifying the publication in the public portal 


\title{
Proteome Analysis of Pyloric Ceca: A Methodology for Fish Feed Development?
}

\author{
Tune Wulff,*, ${ }^{\dagger}$ Jørgen Petersen, ${ }^{\S}$ Mette R. Nørrelykke, ${ }^{\#}$ Flemming Jessen, ${ }^{\dagger}$ and Henrik H. Nielsen ${ }^{\dagger}$ \\ ${ }^{\dagger}$ Division of Industrial Food Research, Technical University of Denmark, Kgs. Lyngby, Denmark \\ ${ }^{\S}$ Department of Biochemistry and Molecular Biology, University of Southern Denmark, Odense, Denmark \\ \#Aller Aqua A/S, Christiansfeld, Denmark \\ Supporting Information
}

ABSTRACT: Changing the protein source of fish feed from fish meal to alternative sources of protein will affect traits such as fish growth, quality, and feed utilization. The present investigation was initiated to introduce a two-dimensional gel electrophoresis based proteomic workflow as a tool to investigate feed effects on fish by analyzing protein changes in the fish gut. The workflow was used to study the effect of substituting fish meal in fish feed by alternative sources of protein. Rainbow trout divided into five groups were fed for 72 days with feeds varying in protein composition. By two-dimensional gel electrophoresis proteins extracted from the pyloric ceca were separated, making it possible to measure the abundance of more than 440 protein spots. The expression of 41 protein spots was found to change due to differences in feed composition. By mass spectrometry 31 of these proteins were identified, including proteins involved in digestion (trypsinogen, carboxylic ester hydrolase, and aminopeptidase). The many expression changes indicated that the trout, when adapting to differences in feed formulation, alter the protein composition of the gut.

KEYWORDS: feed utilization, fish feed, Oncorhynchus mykiss, proteomic, pyloric ceca, two-dimensional gel electrophoresis

\section{INTRODUCTION}

Aquaculture is a fast-growing industry, currently providing $>30 \%$ of the fish used for human consumption. A major obstacle in the production of fish in aquaculture is to ensure continued access to high-quality fish feed. Fish meal has traditionally been the main protein source in fish feed, but is now in short supply, resulting in reduced availability and rising prices. Considerable commercial interest has therefore focused on developing new types of fish feed in which the inclusion of fish meal is reduced by adding alternative sources of protein. In fish feed for rainbow trout alternative diets have included substitution of fish meal with soybean meal, ${ }^{1,2}$ pea meal, ${ }^{3}$ corn products, ${ }^{4}$ and animal byproducts such as blood meal, bone meal, and feather meal. ${ }^{5}$ However, changing the protein source from fish meal to alternative sources of protein can affect growth $^{1,3-5}$ and feed utilization and digestibility. ${ }^{2,6}$ Changing protein sources not only influences growth and feed utilization but also a changed quality of the fish as reflected in differences in the sensory evaluation has been found. ${ }^{7,8}$ The origin of differences in quality between fish fed different types of feed formulations, however, remains to be established. Tests of digestibility and effects of differences in feed formulation on growth and quality are normally performed by in vivo fish trials, but such trials are time-consuming and expensive, ${ }^{9}$ and attempts has been made to develop quick in vitro digestive methods simulating fish digestion. ${ }^{9-11}$ Therefore, a new approach for developing new types of fish feed could be to investigate the physiological impact the feed has on the fish and correlate this information to growth and quality. When feed enters the gastrointestinal system, the pyloric ceca (PC) (accounting for $70 \%$ of the gut) is after the stomach the first organ in contact with the feed. When the feed is changed, the PC is therefore challenged and has to adapt to handle the new feed components. Such adaptations include morphological changes such as enteritis of the intestine $e^{2,12}$ or changes in activity and levels of selected enzymes including amylase and maltase within the gut. ${ }^{13-15}$ One way to study feed-induced adaptations of a fish is to analyze the protein composition of a tissue by proteome analysis. Using proteome analysis based on two-dimensional gel electrophoresis (2-DE) it has been already established that changing the protein source in fish feed will alter the protein expression of the liver of rainbow trout ${ }^{16,17}$ (reviewed in ref 18). The present study was initiated to investigate if a proteomic methodology will be able to reveal changes in protein profiles in PCs from rainbow trout, which were fed diets in which the included protein originated from different sources. As such, proteome analysis could be used as a methodology to elucidate if changes in feed utilization, fish growth, and the quality of the fish can originate from or be mirrored by differences in the protein composition of the gut. The workflow included extraction of proteins from the PC and separation by 2 -DE followed by identification of proteins using mass spectrometry.

\section{MATERIALS AND METHODS}

Fish Husbandry, Experimental Design, and Sampling of Pyloric Ceca. Five groups of rainbow trout (Oncorhynchus mykiss) with an average weight of $85 \pm 6 \mathrm{~g}$ at the beginning of the experiment

Received: April 19, 2012

Revised: August 1, 2012

Accepted: August 6, 2012

Published: August 6, 2012 
Table 1. Main Protein Source and Proximate Composition and Energy Content of the Five Types of Fish Feed

\begin{tabular}{|c|c|c|c|c|c|c|c|c|}
\hline feed & protein source (\%) & dry matter $(\%)$ & protein $(\%)$ & fat $(\%)$ & carbohydrate (\%) & $\operatorname{ash}(\%)$ & gross energy (kcal/kg) & metabolic energy $(\mathrm{kcal} / \mathrm{kg})$ \\
\hline A & fish meal: 61 & 91.7 & 45.7 & 27.7 & 10.7 & 7.6 & 5760 & 5186 \\
\hline B & fish meal: 36 & 93.0 & 41.5 & 28.5 & 15.5 & 7.5 & 5580 & 4587 \\
\hline $\mathrm{C}$ & $\begin{array}{l}\text { fish meal: } 36 \\
\text { blood meal: } 8\end{array}$ & 93.4 & 40.3 & 28.0 & 17.6 & 7.5 & 5690 & 4694 \\
\hline $\mathrm{D}$ & $\begin{array}{l}\text { fish meal: } 18 \\
\text { pea protein: } 18\end{array}$ & 92.7 & 42.4 & 27.4 & 16.6 & 6.3 & 5643 & 4619 \\
\hline $\mathrm{E}$ & $\begin{array}{l}\text { fish meal: } 18 \\
\text { pea protein: } 18 \\
\text { blood meal: } 8\end{array}$ & 92.3 & 41.0 & 28.7 & 16.7 & 6.0 & 5784 & 4763 \\
\hline
\end{tabular}

were kept in tanks with recirculated water at a temperature of $8.6 \pm 0.7$ ${ }^{\circ} \mathrm{C}$. Each tank was $1.1 \mathrm{~m} \times 1.1 \mathrm{~m}$ with a $0.45 \mathrm{~m}$ water level and contained between 104 and 107 fish. The fish were exposed to light from 8 a.m. to 10 p.m. during the whole period. The groups were fed five different experimental feeds supplied by the Danish fish feed producer Aller Aqua. The feeds were produced by a standardized extrusion process and contained various ratios and amounts of fish meal, pea protein, and blood meal (Table 1). The amino acid profiles of the five feed formulations are found in the Supporting Information. Blood meal and pea protein are used in commercial feeds, and the impacts of these protein sources are therefore relevant in relation to commercial aquaculture. The groups were fed five different feeds (Aller Aqua) containing various types and ratios of marine and vegetable protein sources (Table 1). The fish were fed daily at $1.3 \%$ of their biomass with feed automats. The amount of feed was regulated from an assumption of a feed conversion of 0.9. At day 0 PC from 10 fish were sampled; 4 were used for proteome analysis. After 72 days, PC from 3 fish from each feed code were sampled for proteome analysis. The average weights of the fish at days 0 and 72 are shown in Figure 1 . Before sampling, the fish were starved for $48 \mathrm{~h}$, allowing the

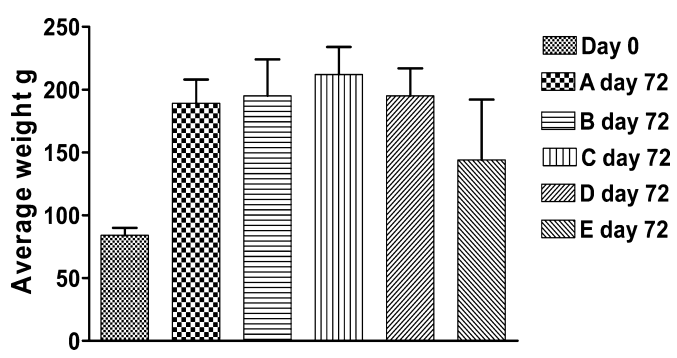

Figure 1. Average weight of rainbow trout at day 0 and after 72 days. Average weight is calculated on the basis of the weight from $10 \mathrm{fish} /$ day 0 and 3 fish/A, B, C, D, and E.

stomach, PC, and intestine to be emptied. The fish were killed by keeping them in water with an overdose of ethyl 3-aminobenzoate methanesulfonate for approximately $5 \mathrm{~min}$. Immediately after the fish were killed, the belly was cut open with scissors and the viscera were quickly taken out. The PC were removed and immediately frozen in liquid nitrogen and stored at $-80{ }^{\circ} \mathrm{C}$ until further analysis.

The experiment was carried out in accordance with EC Directive 86/609/EEC for animal experiments. The study did not require approval by the Animal Experiments Inspectorate in Denmark, as animals killed solely for the use of their organs or tissues are not regulated by the Animal Experimentation Act as defined in the Directive 2010/63/EU of the European Parliament and of the Council of September 22, 2010, on the protection of animals used for scientific purposes. The Technical University of Denmark (DTU Aqua) is authorized to keep and rear fish for research purposes under the
Central Husbandry Register, Ministry for Food, Agriculture and Fisheries.

Proximate Analysis of Feed. Protein was analyzed according to the Kjeldahl method (crude protein $=6.25 \times$ Kjeldahl nitrogen) $($ ISO $5928-2,2005)$. Lipid was analyzed according to the method by Bligh and Dyer. ${ }^{19}$ Dry matter was analyzed according to NMKL 23 (1991). Carbohydrate including crude fibers was estimated as $\mathrm{N}$-free extract $=$ dry matter - protein - lipid - ash.

Extraction of Digestive Enzymes and Proteins from the Pyloric Ceca. Digestive enzymes and proteins were obtained by passive extraction after the method given in ref 10 . The extraction procedure was modified so whole PC (weight ranging from 3.3 to 10.6 g) was gently shaken in 10 volumes of water at $2{ }^{\circ} \mathrm{C}$ for $24 \mathrm{~h}$. After extraction, tissue was removed, and the crude extract was centrifuged in $15 \mathrm{~min}$ at $3500 \mathrm{~g}$ at $5{ }^{\circ} \mathrm{C}$. The supernatant was stored at $-80^{\circ} \mathrm{C}$ until further analysis.

2D-SDS-PAGE. On the basis of Lowry protein determination ${ }^{20}$ using a Shimadzu UV 160 spectrophotometer (GMI), crude extract containing $386 \mu \mathrm{g}$ of protein dissolved in $450 \mu \mathrm{L}$ of buffer containing 1 $\mathrm{mM}$ EDTA and $50 \mathrm{mM}$ Tris base, $\mathrm{pH}$ 7.4, was mixed with 3.3 volumes of $65 \%$ TCA. After precipitation, the sample was centrifuged at $15000 \mathrm{~g}$ at $4{ }^{\circ} \mathrm{C}$ for $15 \mathrm{~min}$. The pellet was washed twice in $1 \mathrm{~mL}$ of $-20{ }^{\circ} \mathrm{C}$ cold acetone, and after drying, the pellet containing $386 \mu \mathrm{g}$ of protein was solubilized in $450 \mu \mathrm{L}$ of reswelling buffer ( $8 \mathrm{M}$ urea, $2 \mathrm{M}$ thiourea, $50 \mathrm{mM}$ DTT, 1.5\% CHAPS, 2\% Pharmalyt 5-8 (Amersham Biosciences), $10 \mathrm{mM}$ trizmabase, and $0.1 \%$ SDS) with Orange $\mathrm{G}$ as dye. From the reswelling buffer $350 \mu \mathrm{L}$ was added to $18 \mathrm{~cm}$ 1-D immobiline drystrip (pI 4-7, Amersham Biosciences) corresponding to $300 \mu \mathrm{g}$ protein/drystrip. After reswelling overnight, proteins were separated according to the $\mathrm{p} I$ by submitting the drystrips to $60000 \mathrm{Vh}$, after which they were stored at $-80^{\circ} \mathrm{C}$. The size separation in the first and second dimensions is described elsewhere. ${ }^{21}$ In short, prior to separation in the first dimension on a Multiphor II (Amersham Biosciences) the 1-D drystrips were reduced for $20 \mathrm{~min}$ in $10 \mathrm{~mL}$ of equilibration buffer (6 M urea, $50 \mathrm{mM}$ Tris- $\mathrm{HCl}, \mathrm{pH} 8.8,30 \% \mathrm{v} / \mathrm{v}$ glycerol, $2 \% \mathrm{w} / \mathrm{v}$ SDS) with $1 \% \mathrm{w} / \mathrm{v}$ DTT followed by $20 \mathrm{~min}$ of alkylation in $10 \mathrm{~mL}$ of equilibration buffer with $4.5 \% \mathrm{w} / \mathrm{v}$ iodoacetamide. Separation in the second dimension was achieved on a $12 \% \mathrm{w} / \mathrm{v}$ SDS-PAGE 22 in a Hoefer Dalt system (Amersham Biosciences) running 10 gels at a time at $15^{\circ} \mathrm{C}$ with a maximum of 40 $\mathrm{mA} /$ gel. The 2-D gels were colloidal Coomassie stained. ${ }^{23}$

Image Analysis. The imaging system Camilla II (Raytest, Germany) was used for digitizing the colloidal Coomassie stained gels. Camera exposure time was set at $200 \mathrm{~ms}$, and the focus light was turned on. Visualization was optimized by applying flat- and geometric-correction; however, no lens correction was necessary. The color setting was gray scale, and gain was set at 200. Pictures were saved in TIFF format, with a pixel size of $100 \mu \mathrm{m}$ and a number format of 16 bit low with no compression.

TIFF files were exported to Progenesis SameSpots (version 3.2, Nonlinear Dynamics, Newcastle, UK) for image analysis. The 
alignments were predominantly based on the automatic generation of vectors within the software. All automatically generated vectors were manually verified. Additional vectors were manually added to a few selected prominent spots on each of the 15 gels. Gel images were warped to a selected master gel based on all vectors, after which spot detection was performed on all gels. The position of the detected spots on all 15 gels was assigned to the master gel creating a complete spot map. All spots on the map were manually edited to remove possible artifacts, and only well-defined and clearly distinguished spots were included in the final data set.

Data Analysis. For data analysis the spot volumes were normalized using the algorithm within Progenesis SameSpots. The univariate data analysis was performed as one-way ANOVA $(p<0.05)$ on each spot individually, followed by the post hoc Tukey test analysis $(p<0.05)$. In addition to this univariate spot by spot comparison using ANOVA, a multivariate linear discrimination analysis, partial least-squares (PLS) regression, was used to find complex differences between two groups. The commercial software The Unscrambler (version 9.1, Camo, Oslo, Norway) was used for this. In brief, the normalized spot volumes constituted the columns in the data matrix ( $X$-matrix) with the rows representing the samples, and the $X$-matrix columns were group scaled $^{24}$ before calculation. The $Y$-vector of the regression contained indicator variables ( 0 or 1$)$ for the groups to be compared. The spots that individually or in combination with other spots varied in amount between groups were selected by a modified jack-knife method (included in the PLS regression analysis) for the estimation of parameter uncertainty in PLS regression. ${ }^{25}$ The regression models were validated by full cross-validation, and spots with regression coefficients significantly $(p<0.05)$ different from 0 were selected and then analyzed by a new PLS regression. This procedure was repeated until the model was optimal (the highest correlation coefficient of the predicted versus known $Y$ ), and the spots in this model were considered to differ significantly between the two groups in question. Principal component analysis (PCA) was used for visualization of overall data variation.

Tryptic Digest. Protein spots visualized by colloidal Coomassie staining were excised from the gel, transferred to $1.5 \mathrm{~mL}$ eppendorf microcentrifuge tubes, and rinsed with $200 \mu \mathrm{L}$ of ultrapure water for $10 \mathrm{~min}$. After two washes in $50 \%$ acetonitrile $/ 25 \mathrm{mM} \mathrm{NH}_{4} \mathrm{CO}_{3}$, the gel pieces were shrunk by adding $30 \mu \mathrm{L}$ of $100 \%$ acetonitrile and subsequently dried in a vacuum centrifuge. The gel pieces were then swollen in a digestion buffer, $50 \mathrm{mM} \mathrm{NH} \mathrm{CO}_{3}, 12.5 \mathrm{ng} / \mu \mathrm{L}$ trypsin (Promega, Madison, WI, USA; modified, sequencing grade) in an icecold water bath. After $45 \mathrm{~min}$, the supernatant was removed and replaced with $30 \mu \mathrm{L}$ of $50 \mathrm{mM} \mathrm{NH}_{4} \mathrm{CO}_{3}$ buffer. Enzymatic cleavage was performed overnight at $37^{\circ} \mathrm{C}$.

Mass Spectrometry. The mass spectrometer was operated in positive ion mode with a resolution of 9000 at full-width halfmaximum using a source temperature of $80{ }^{\circ} \mathrm{C}$ and a nitrogen countercurrent flow rate of approximately $60 \mathrm{~L} / \mathrm{h}$. MS analyses were performed using $2 \mathrm{~s}$ scans. Instrument settings for data-dependent analysis were performed using the three most abundant ions in each cycle MS $2 \mathrm{sec}(\mathrm{m} / z$ 300-1500) and maximum $10 \mathrm{sec}$ MS/MS (502000), $60 \mathrm{~s}$ dynamic exclusion. Processing of raw data was done using external calibration with fragment ions of glufibronectin resulting in mass errors of typically $10-20 \mathrm{ppm}$ in the $\mathrm{m} / z$ range 50-2000. Raw data were processed using ProteinLynx Global Server 2.0 (smooth 4/2 Savitzky Golay, center four channels/80\% centroid). The resulting MS/MS data set was exported in MicroMass pkl format for automated peptide identification using an in-house MASCOT server (version 2.1.3) (Matrix Sciences, London, UK) or using GPMAW software (version 7.01) from Lighthouse data. Searches were performed against the NCBI nonredundant database with the following search criteria: tryptic peptides, one missed cleavage allowed; $\pm 50 \mathrm{ppm}$ tolerance for MS and 0.2 Da for MS/MS fragment ions; oxidation of methionine, deamidation of asparagines and glutamine, and carbamidomethylation of cysteine were specified as variable modifications.

\section{RESULTS}

Two-Dimensional Gel Electrophoresis. In this study differences in protein expression in the PC from rainbow trout were investigated in response to five different types of feed (Table 1) for 72 days. Proteins were extracted from the PC as a crude extract and were separated on 2-D gels (Figure 2),

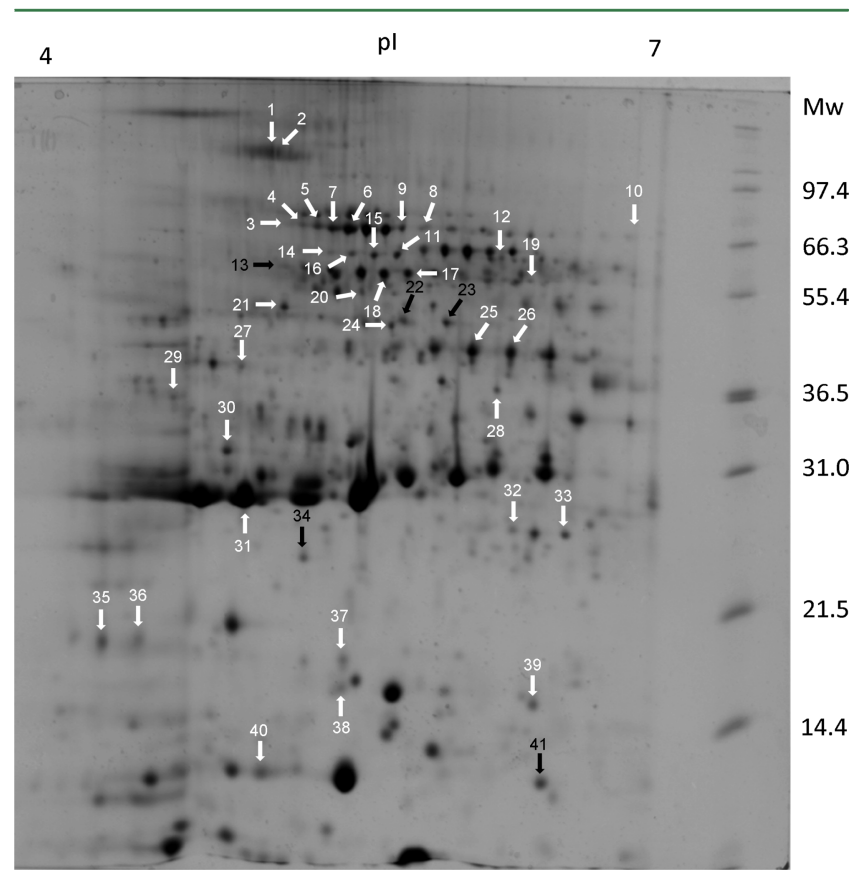

Figure 2. Representative 2-DE gel of proteins from the pyloric ceca from rainbow trout. Proteins of interest based on ANOVA and PLS analysis are indicated by arrows. A white arrow designates that the protein has been identified with LC-MS/MS, whereas a black arrow designates that the protein has not been identified.

resulting in 440 different spots being visualized by colloidal Coomassie staining. The spots included in the data set covered a molecular weight of $10-120 \mathrm{kDa}$ and a $\mathrm{pI}$ range of $4-7$. To visualize the variation in the data, a PCA including all 440 spots was performed. The projection of the samples onto the first two principal components accounting for $33 \%$ of the variation in the samples is shown in Figure 3. It is evident from Figure 3 that samples from the same feeding group are positioned close together with the exception of one sample feeding group D. This indicates that the proteome variation between feeding groups exceeded the variation within the feeding groups. Additionally, it can be seen in Figure 3 that the variation shown in this plot correlates with the feed content of fish meal with the highest content in the lower left part of the plot and a decreasing content toward the upper right. The differences in protein expression between the five feeding groups were established using ANOVA, by which each spot was analyzed individually. Using the ANOVA analysis 22 spots that were differently expressed in response to the five different feeds were found (Table 2). To find more complex protein expression patterns comprising more spots, which in combination differentiate between the feeding groups, multivariate data analysis was used. Thus, five PLS regression analyses were performed to establish models able to differentiate the feeding groups one by one from the four others (Table 2). By this procedure PLS regression models differentiating feeding groups $\mathrm{A}, \mathrm{B}$, and $\mathrm{E}$ from the remaining groups, respectively, were 
PC-2

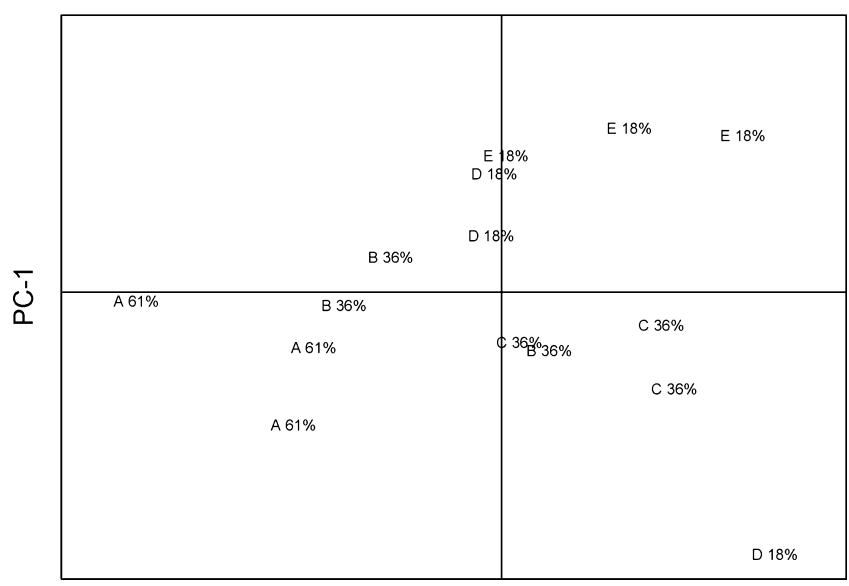

Figure 3. Principal component analysis of all 440 spots. The five different groups, A, B, C, D, and E, are each represented by three samples. The given percentages specify the fish meal part of the proteins in the feed. The first two principal components account for 22 and $11 \%$, respectively, of the variation within the samples.

established, whereas such models could not be established for feeding groups $\mathrm{C}$ and $\mathrm{D}$. For feeding groups $\mathrm{A}, \mathrm{B}$, and $\mathrm{E}$ the unique protein expression profiles consisted of 13,10 , and 4 spots, respectively. Two spots were included in two models (groups A and B); thus, in total 25 different spots (Table 2) were found by the multivariate approach. The cross-validation showed that all three models were able to discriminate $100 \%$ between the groups in question. It was not possible to establish PLS regression models differentiating feeding group $\mathrm{C}$ or $\mathrm{D}$ from the remaining groups.

MS/MS. Proteins affected by the different types of feed were localized on preparative gels and their identification was attempted by LC-MS/MS, resulting in the positive identification of 31 named proteins. Identifications were based on peptide fragmentation, and in most cases two or more fragmented peptides were used for protein identification: in the cases when only one peptide was used for identification, manual de novo sequencing of the peptide agreed with the sequence found in the Mascot database search (Table 3). Serum albumin precursor was by far the most abundant, being represented in 11 different spots, but also a number of enzymes such as trypsinogen, carboxylic ester hydrolase maltaseglucoamylase, and aminopeptidase were identified. In the case of three protein spots identification was unsuccessful most likely due to low protein amount or unknown proteins not present in the database.

\section{DISCUSSION}

It is evident that different compositions of fish feed will influence growth, health, feed utilization, and also quality of rainbow trout. ${ }^{6,26-28}$ Therefore, to obtain maximal weight gain and optimal quality, even small differences in feed composition can be important. Normally, the effects of different feed compositions are evaluated on the basis of the degree of digestibility, utilization, and sensory evaluation. The purpose of this investigation was to elucidate if proteome analysis could provide knowledge on how the differences in fish feed are reflected in the protein composition of the gut. This could help explain if the differences seen in quality and growth originate from changes in the protein composition and thereby feed uptake of the gut as represented by the PC.

Implication of the Used Method. The main challenge in the introduction of a proteomic approach is to ensure that the obtained results are correct and reproducible. When 2-DE gel electrophoresis is run, a cause of concern is that very abundant proteins can hide less abundant proteins. The problem arose in this investigation because the excessive amounts of proteins originating from the fish feed would hide proteins originating from the gut. To address this problem, the fish were starved prior to sampling to remove proteins originating from the fish feed. A number of studies have investigated the effects of starvation on enzyme activity in fish gut. ${ }^{27,29,30}$ In rainbow trout 5 days of starvation increases the protease activity, whereas amylase activities are decreased. ${ }^{31}$ In PC of the Atlantic salmon the protein/tissue ratio remains constant but there is observed a slight decrease in total protein amount. ${ }^{30}$ Therefore, a short period of starvation prior to sampling represents a suitable approach, which still allows for a correct reproduction of protein composition of the PC in rainbow trout during feeding.

Effects of Feed Composition. From Figure 3 it is clear that the differences in feed composition also affect the protein composition of the PC. This means that the five different types of fish feed could successfully be distinguished on the basis of differences in protein expression obtained using a proteomic methodology. Table 3 provides the identity of the proteins, and it is clear that a large variety of different proteins were changing in abundance in response to the different types of feed. Compared to salmon, the trout seems to be more prone to adaptation, indicated by its increased ability to gain weight compared to salmon when fed a fish meal and a fish meal/ soybean meal based diet. ${ }^{2}$ Previous studies investigating feed utilization in rainbow trout show that the trout is very capable of sustaining a high degree of feed utilization in terms of digestibility and growth when different compositions of feed are used. ${ }^{14,32}$ On the basis of this investigation some of this flexibility could originate from the capability of the trout to alter the protein composition of the gut, leading to an optimized digestibility when feed composition is changed. This means that even fish feed with suboptimal compositions could be utilized in a near-optimal way by the trout. One of the most important components of the fish feed is fish meal. This is a problem largely because it is an expensive protein source but also because it is increasingly becoming in short supply. On the basis of Figure 3 it is clear that the amount of fish meal was clearly reflected in the protein expression profiles. This means that besides the differences shown in Figure 3, fish meal as a single ingredient will also result in specific adaptations of PC. This is very interesting considering the great interest there is in replacing fish meal with alternative sources of proteins. ${ }^{3,4}$ From the current investigation it seems that even though differences in the percentage of included fish meal were not reflected in the growth rate, it would, however, lead to specific adaptation within the gut.

Enzymes. Enzymes normally associated with fish gut were differently expressed in response to the different formulations of fish feed (Table 2). Trypsin belongs to the serine protease family and is one of the major digestive enzymes. The activity and yield of the enzyme have been characterized in PC from rainbow trout, ${ }^{33}$ and it shows that the activity and amount are altered by differences in feed composition. In the present study trypsinogen, the precursor for active trypsin, was found to be regulated in response to the differences in feed composition. 
Table 2. Protein Changes in the Pyloric Ceca of Rainbow Trout after 72 Days of Altered Feed Formulation (A-E) ${ }^{a}$

\begin{tabular}{|c|c|c|c|c|c|c|}
\hline spot & protein name & A & $\mathrm{B}$ & $\mathrm{C}$ & $\mathrm{D}$ & $\mathrm{E}$ \\
\hline 1 & maltase-glucoamylase, intestinal-like & 1 & 0.79 & 0.70 & 0.66 & 0.64 \\
\hline 2 & maltase-glucoamylase, intestinal-like & 1 & 0.67 & 0.59 & 0.59 & 0.58 \\
\hline 3 & serum albumin & $1 \mathrm{a}$ & $1.08 \mathrm{a}$ & $1.47 \mathrm{a}$ & $1.81 \mathrm{ab}$ & $2.90 \mathrm{~b}$ \\
\hline 4 & albumin & 1 a & $1.08 \mathrm{a}$ & $1.23 \mathrm{a}$ & $1.94 \mathrm{ab}$ & $2.77 \mathrm{~b}$ \\
\hline 5 & serum albumin & 1 a & $1.18 \mathrm{a}$ & $1.44 \mathrm{a}$ & $1.78 \mathrm{ab}$ & $2.68 \mathrm{~b}$ \\
\hline 6 & serum albumin & 1 a & $1.12 \mathrm{a}$ & $1.37 \mathrm{a}$ & $1.35 \mathrm{a}$ & $1.98 \mathrm{~b}$ \\
\hline 7 & serum albumin & 1 a & $1.14 \mathrm{a}$ & $1.31 \mathrm{a}$ & 1.47 a & $2.12 \mathrm{~b}$ \\
\hline 8 & albumin & 1 a & 0.96 a & $1.80 \mathrm{ab}$ & $1.59 \mathrm{ab}$ & $3.04 \mathrm{~b}$ \\
\hline 9 & serum albumin & 1 a & $1.06 \mathrm{ab}$ & $1.50 \mathrm{ab}$ & $1.55 \mathrm{ab}$ & $2.62 \mathrm{~b}$ \\
\hline 10 & serum albumin & $1 \mathrm{a}$ & $1.53 \mathrm{ab}$ & $1.76 \mathrm{ab}$ & $1.76 \mathrm{ab}$ & $2.32 \mathrm{~b}$ \\
\hline 11 & serum albumin & $1 \mathbf{a}$ & $1.16 \mathrm{a}$ & $1.72 \mathrm{a}$ & $1.60 \mathrm{a}$ & $2.75 \mathrm{~b}$ \\
\hline 12 & carboxylic ester hydrolase & 1 & 1.29 & 1.10 & 1.11 & 1.10 \\
\hline 13 & not identified & $1 \mathrm{ab}$ & $0.78 \mathrm{a}$ & $1.16 \mathrm{ab}$ & $2.06 \mathrm{ab}$ & $2.18 \mathrm{~b}$ \\
\hline 14 & serum albumin & 1 a & $1.21 \mathrm{a}$ & $1.79 \mathrm{ab}$ & $2.45 \mathrm{ab}$ & $3.47 \mathrm{~b}$ \\
\hline 15 & serum albumin & 1 a & $1.19 \mathrm{a}$ & $1.26 \mathrm{ab}$ & $1.69 \mathrm{ab}$ & $2.47 \mathrm{~b}$ \\
\hline 16 & serum albumin & 1 a & $1.05 \mathrm{a}$ & $1.41 \mathrm{a}$ & 1.59 a & $2.90 \mathrm{~b}$ \\
\hline 17 & serum albumin 2 precursor & 1 a & $2.17 \mathrm{a}$ & $1.64 \mathrm{ab}$ & $1.02 \mathrm{ab}$ & $1.72 \mathrm{ab}$ \\
\hline 18 & hypothetical protein LOC 100136575 precursor & 1 & 1.69 & 1.46 & 1.08 & 1.35 \\
\hline 19 & selenium-binding protein 1 & 1 & 0.46 & 0.35 & 0.44 & 0.49 \\
\hline 20 & flavodoxin & 1 & 0.71 & 0.85 & 0.88 & 0.77 \\
\hline 21 & $\alpha$-1-antiproteinase-like protein & 1 a & $0.82 \mathrm{ab}$ & $0.58 \mathrm{~b}$ & $0.69 \mathrm{~b}$ & $0.71 \mathrm{ab}$ \\
\hline 22 & not identified & 1 a & $0.84 \mathrm{ab}$ & $0.55 \mathrm{~b}$ & $0.67 \mathrm{ab}$ & $0.59 \mathrm{ab}$ \\
\hline 23 & not identified & 1 & 0.66 & 0.37 & 0.46 & 0.40 \\
\hline 24 & aminoacylase-1 & 1 & 0.73 & 0.82 & 0.68 & 0.64 \\
\hline 25 & glyceraldehyde-3-phosphate dehydrogenase & 1 a & $0.73 \mathrm{ab}$ & $0.63 \mathrm{ab}$ & $0.74 \mathrm{ab}$ & $0.50 \mathrm{~b}$ \\
\hline 26 & glyceraldehyde-3-phosphate dehydrogenase & $1 \mathrm{ab}$ & $1.01 \mathrm{a}$ & $0.83 \mathrm{ab}$ & $0.83 \mathrm{ab}$ & $0.70 \mathrm{~b}$ \\
\hline 27 & probable aminopeptidase NPEPL1 & 1 a & $0.62 \mathrm{ab}$ & $0.77 \mathrm{ab}$ & $0.90 \mathrm{ab}$ & $0.58 \mathrm{~b}$ \\
\hline 28 & carboxypeptidase A1 & 1 a & $0.76 \mathrm{ab}$ & $0.56 \mathrm{~b}$ & $0.55 \mathrm{~b}$ & $0.80 \mathrm{ab}$ \\
\hline 29 & leukocyte elastase inhibitor & 1 a & $0.64 \mathrm{ab}$ & $0.35 \mathrm{~b}$ & $0.50 \mathrm{ab}$ & $0.43 \mathrm{ab}$ \\
\hline 30 & transferrin & 1 & 1.59 & 0.94 & 1.09 & 1.09 \\
\hline 31 & trypsinogen & 1 & 1.15 & 0.86 & 0.85 & 0.90 \\
\hline 32 & superoxide dismutase, mitochondrial precursor & 1 & 1.33 & 1.04 & 1.32 & 1.00 \\
\hline 33 & superoxide dismutase, mitochondrial precursor & 1 & 0.82 & 0.92 & 0.81 & 0.63 \\
\hline 34 & leukocyte elastase inhibitor & 1 a & $0.82 \mathrm{ab}$ & $0.92 \mathrm{a}$ & $0.81 \mathrm{ab}$ & $0.63 \mathrm{~b}$ \\
\hline 35 & filamin-A & 1 & 0.67 & 0.75 & 0.94 & 0.65 \\
\hline 36 & filamin-A & 1 & 0.53 & 0.73 & 0.70 & 0.70 \\
\hline 37 & cystathionine $\gamma$-lyase & 1 & 1.43 & 1.28 & 1.22 & 0.91 \\
\hline 38 & $\mathrm{Cu} / \mathrm{Zn}$-superoxide dismutase & 1 a & $3.24 \mathrm{ab}$ & $2.76 \mathrm{ab}$ & $3.43 \mathrm{~b}$ & $1.89 \mathrm{ab}$ \\
\hline 39 & complement $\mathrm{C} 3$ & 1 & 1.96 & 1.77 & 1.41 & 1.30 \\
\hline 40 & fatty acid binding protein & 1 & 1.56 & 1.82 & 1.27 & 1.46 \\
\hline 41 & not identified & 1 a & $1.68 \mathrm{ab}$ & $2.35 \mathrm{~b}$ & $1.46 \mathrm{ab}$ & $2.30 \mathrm{~b}$ \\
\hline
\end{tabular}

${ }^{a}$ Protein spots that differed in protein abundance among the five different feed formulations were established using ANOVA and PLSR. Following the ANOVA Tukey's multiple-comparison test was applied to establish which feed formulations differed significantly. These are highlighted in bold; within each spot feed codes marked "a" differ significantly from feed codes marked "b", whereas feed codes marked "ab" do not differ significantly from any other feed. Within the PLS analysis feed protein spots used to differentiate between the feeding groups are highlighted in bold and have no letter.

Another enzyme that was differently expressed is aminopeptidase. This enzyme plays an essential role in the absorption of dietary proteins, ${ }^{34}$ but interestingly it is also involved in the digestion of products from trypsin, which are then transported into the intestinal cells. ${ }^{35}$ The regulation of these two proteins therefore could indicate a coordinated enzymatic change in response to a change in feed composition. In this study we have not measured the enzyme activity, and the impact of the different types of fish feed on enzyme activity therefore remains inconclusive. However, the observation that enzymes such as trypsin, carboxylic ester hydrolase, and aminopeptidase were regulated on the protein level provides a starting point for further investigation.
Serum Albumin. Another important change following feed intake is the fact that digestion and absorption in the gut will result in increased gastrointestinal blood flow. ${ }^{36,37}$ However, it is still not fully clear if and to what extent different compositions of feeds will elicit different postprandial gastrointestinal blood flow, even though differences in blood flow have been shown in rainbow trout. ${ }^{38}$ Serum albumin is one of the most dominant proteins of blood plasma in trout ${ }^{39}$ and was, in this study, the protein most affected by the differences in feed composition (Table 2). In a number of studies it has been demonstrated that gastrointestinal blood flow increases after feeding in fish. ${ }^{37,40,41}$ Investigating the effect of proteins and lipids, Seth et al. found that individual nutritional components 
Table 3

\begin{tabular}{|c|c|c|c|c|c|}
\hline spot & protein name & accession no. ${ }^{a}$ & $\mathrm{MM} / \mathrm{p} I^{b}$ & seq cov/pep match ${ }^{c}$ & Mascot score $^{d}$ \\
\hline 1 & maltase-glucoamylase, intestinal-like $\left(\mathrm{e}^{0}\right)$ & gil348508446 & $195014 / 5.88$ & $1 / 2$ & 94 \\
\hline 2 & maltase-glucoamylase, intestinal-like $\left(\mathrm{e}^{0}\right)$ & gil348508446 & $195014 / 5.88$ & $0 / 1$ & 48 \\
\hline 3 & serum albumin & gil1351907 & $69248 / 5.82$ & $13 / 7$ & 294 \\
\hline 4 & albumin & gil229552 & $66088 / 5.76$ & $8 / 5$ & 198 \\
\hline 5 & serum albumin & gil1351907 & $69248 / 5.82$ & $13 / 8$ & 456 \\
\hline 6 & serum albumin & gil1351907 & $69248 / 5.82$ & $14 / 8$ & 499 \\
\hline 7 & serum albumin & gil1351907 & $69248 / 5.82$ & $17 / 9$ & 591 \\
\hline 8 & albumin & gil229552 & $66088 / 5.76$ & $8 / 5$ & 183 \\
\hline 9 & serum albumin & gil1351907 & $69248 / 5.82$ & $16 / 9$ & 373 \\
\hline 10 & serum albumin & gil1351907 & $69248 / 5.82$ & $10 / 6$ & 199 \\
\hline 11 & serum albumin & gil1351907 & $69248 / 5.82$ & $14 / 8$ & 355 \\
\hline 12 & carboxylic ester hydrolase & gil397695 & $59038 / 6.49$ & $2 / 1$ & 54 \\
\hline 14 & serum albumin & gil1351907 & $69248 / 5.82$ & $16 / 9$ & 425 \\
\hline 15 & serum albumin & gil1351907 & $69248 / 5.82$ & $16 / 8$ & 440 \\
\hline 16 & serum albumin & gil76445989 & $53890 / 6.09$ & $14 / 6$ & 307 \\
\hline 17 & serum albumin 2 precursor & gil185133567 & $67015 / 5.44$ & $3 / 2$ & 100 \\
\hline 18 & serum albumin 1 precursor $\left(\mathrm{e}^{0}\right)$ & gil185132509 & $67107 / 5.44$ & $6 / 4$ & 164 \\
\hline 19 & selenium-binding protein 1 & gil213513151 & $51264 / 6.28$ & $15 / 5$ & 145 \\
\hline 20 & flavodoxin & gil111017066 & $19027 / 5.69$ & $5 / 1$ & 52 \\
\hline 21 & $\alpha$-1-antiproteinase-like protein & gill185132174 & $47498 / 5.86$ & $7 / 2$ & 145 \\
\hline 24 & aminoacylase-1 & gil213515484 & $47003 / 5.28$ & $14 / 5$ & 219 \\
\hline 25 & glyceraldehyde-3-phosphate dehydrogenase & gil46401622 & $36222 / 6.07$ & $16 / 3$ & 151 \\
\hline 26 & glyceraldehyde-3-phosphate dehydrogenase & gil185132746 & $36266 / 6.37$ & $7 / 2$ & 56 \\
\hline 27 & probable aminopeptidase NPEPL1 & gil213513654 & $55428 / 6.88$ & $9 / 3$ & 191 \\
\hline 28 & carboxypeptidase A1 & gil213513306 & $47536 / 5.23$ & $9 / 3$ & 167 \\
\hline 29 & leukocyte elastase inhibitor $\left(\mathrm{e}^{0}\right)$ & gil356640261 & $42636 / 5.37$ & $2 / 1$ & 64 \\
\hline 30 & transferrin & gil5837767 & $75400 / 6.03$ & $4 / 2$ & 154 \\
\hline 31 & trypsinogen & gil971196 & $25709 / 5.33$ & $18 / 3$ & 137 \\
\hline 32 & superoxide dismutase, mitochondrial precursor $\left(\mathrm{e}^{0}\right)$ & gil223647010 & $24933 / 7.82$ & $11 / 2$ & 80 \\
\hline 33 & superoxide dismutase, mitochondrial precursor $\left(\mathrm{e}^{0}\right)$ & gil223647010 & $24933 / 7.82$ & $11 / 2$ & 125 \\
\hline 35 & filamin-A & gil 189535920 & $280586 / 5.73$ & $0 / 1$ & 104 \\
\hline 36 & filamin-A & gil189535920 & $280586 / 5.73$ & $0 / 1$ & 108 \\
\hline 37 & cystathionine $\gamma$-lyase & gil118463798 & $38305 / 5.68$ & $2 / 1$ & 55 \\
\hline 38 & $\mathrm{Cu} / \mathrm{Zn}$-superoxide dismutase & gil185132317 & $15745 / 5.67$ & $42 / 4$ & 294 \\
\hline 39 & complement C3 & gil1352103 & $181990 / 6.12$ & $1 / 2$ & 61 \\
\hline 40 & fatty acid binding protein & gil11095781 & $13426 / 5.44$ & $67 / 4$ & 219 \\
\hline
\end{tabular}

${ }^{a}$ Accession numbers from the nrNCBI database. ${ }^{b}$ Theoretical molecular mass of the identified protein and its corresponding isoelectric point. ${ }^{c}$ Percentage of amino acids of the identified protein covered by the MS/MS analysis and the number of peptides matching the identified protein. ${ }^{d}$ The scores obtained by searching the MS/MS data sets in the nrNCBI database using the Mascot search engine. The score for a MS/MS match is based on the absolute probability $(p)$ that the observed match between the experimental data and the database sequence is a random event. Individual ion scores $>40$ indicate identity or extensive homology $(p<0.05)$. ${ }^{e}$ Protein identification resulted in the identification of unnamed protein. The obtained sequence was then used for a blast search ( $e$ value is given for chosen protein) by the NCBI BLAST service (http://blast.ncbi. nlm.nih.gov) against the complete database, and an annotated homologue was chosen as the representative.

can have different effects on gut blood flow. ${ }^{38}$ In addition, fatty acid binding protein was also found to be regulated in this study (Table 2). Playing an important role in fatty acid trafficking and metabolism in the gut, ${ }^{42,43}$ its regulation is interesting and again shows the influence of fish feed on cellular mechanism within the PC. The observed difference in serum albumin among the five groups might therefore be a result of the different feed compositions eliciting different degrees of blood flow to the PC. An important consideration regarding the method is obviously that during the extraction of proteins different amounts of blood would be included in the sample, which could explain the dominance of serum albumin. However, the clear separation of the five groups in Figure 3 based on the PCA would not be possible if the amount of serum was random. This leads to the conclusion that the changes in serum albumin were a functional response to the differences in feed composition.
Concluding Remarks. We successfully used a proteomic methodology to investigate the effect of changing the origin of protein in fish feed from fish meal based feed types to feed types with lowered levels of fish meal.

Using this presented workflow, proteins were extracted from the PC of rainbow trout and subsequently separated using 2DE. Although this study included only a limited number of samples, it has clearly demonstrated that changes in the fish feed composition resulted in protein changes in the PC of rainbow trout. This could be the result of important feedrelated adaptations reflecting growth rate and/or quality aspects. Further studies should reveal if differences in growth rate and quality between fish fed diets of different compositions can be mirrored by such changes in protein composition of the fish gut, thus making proteome analysis of PC a relevant tool in the development of new feed formulations. 


\section{ASSOCIATED CONTENT}

\section{S Supporting Information}

Amino acid composition of feeds. This material is available free of charge via the Internet at http://pubs.acs.org.

\section{AUTHOR INFORMATION}

\section{Corresponding Author}

* Postal address: Section for Biological Quality, Division of Industrial Food Research, National Food Institute Technical University of Denmark, Søltofts Plads, Bygn. 221, 2800 Kgs. Lyngby Denmark. E-mail: tuwu@food.dtu.dk. Phone: +45 45254920. Fax: +4545884774 .

\section{Funding}

This work was supported by Danish Ministry of Food, Agriculture and Fisheries (Grant 3414-07-01880).

\section{Notes}

The authors declare no competing financial interest.

\section{ACKNOWLEDGMENTS}

We thank the Section for Aquaculture, DTU Aqua, for carrying out the farming of rainbow trout and Karin Reimers for skillful technical assistance.

\section{REFERENCES}

(1) Kaushik, S. J.; Cravedi, J. P.; Lalles, J. P.; Sumpter, J.; Fauconneau, B.; Laroche, M. Partial or total replacement of fish-meal by soybean protein on growth, protein-utilization, potential estrogenic or antigenic effects, cholesterolemia and flesh quality in rainbow-trout, Oncorhynchus mykiss. Aquaculture 1995, 133, 257-274.

(2) Refstie, S.; Korsoen, O. J.; Storebakken, T.; Baeverfjord, G.; Lein, I.; Roem, A. J. Differing nutritional responses to dietary soybean meal in rainbow trout (Oncorhynchus mykiss) and Atlantic salmon (Salmo salar). Aquaculture 2000, 190, 49-63.

(3) Thiessen, D. L.; Campbell, G. L.; Adelizi, P. D. Digestibility and growth performance of juvenile rainbow trout (Oncorhynchus mykiss) fed with pea and canola products. Aquacult. Nutr. 2003, 9, 67-75.

(4) Gaylord, T. G.; Barrows, F. T.; Rawles, S. D.; Liu, K.; Bregitzer, P.; Hang, A.; Obert, D. E.; Morris, C. Apparent digestibility of nutrients and energy in extruded diets from cultivars of barley and wheat selected for nutritional quality in rainbow trout Oncorhynchus mykisx. Aquaculture Nutr. 2009, 15, 306-312.

(5) El-Haroun, E. R.; Azevedo, P. A.; Bureau, D. P. High dietary incorporation levels of rendered animal protein ingredients on performance of rainbow trout Oncorhynchus mykiss (Walbaum, 1972). Aquaculture 2009, 290, 269-274.

(6) Glencross, B.; Evans, D.; Hawkins, W.; Jones, B. Evaluation of dietary inclusion of yellow lupin (Lupinus luteus) kernel meal on the growth, feed utilisation and tissue histology of rainbow trout (Oncorhynchus mykiss). Aquaculture 2004, 235, 411-422.

(7) Baron, C. P.; Hyldig, G.; Jacobsen, C. Does feed composition affect oxidation of rainbow trout (Oncorhynchus mykiss) during frozen storage? J. Agric. Food Chem. 2009, 57, 4185-4194.

(8) de Francesco, M.; Parisi, G.; Medale, F.; Lupi, P.; Kaushik, S. J.; Poli, B. M. Effect of long-term feeding with a plant protein mixture based diet on growth and body/fillet quality traits of large rainbow trout (Oncorhynchus mykiss). Aquaculture 2004, 236, 413-429.

(9) Dimes, L. E.; Haard, N. F.; Dong, F. M.; Rasco, B. A.; Forster, I. P.; Fairgrieve, W. T.; Arndt, R.; Hardy, R. W.; Barrows, F. T.; Higgs, D. A. Estimation of protein digestibility. 2. In-vitro assay of protein in salmonid feeds. Comp. Biochem. Physiol. A-Physiol. 1994, 108, 363370.

(10) Bassompierre, M.; Børresen, T.; Sandfeld, P.; Rønsholdt, B.; Zimmermann, W.; Mclean, E. An evaluation of open and closed systems for in vitro protein digestion of fish meal. Aquacult. Nutr. 1997, 3 (7), 153-159.
(11) Rungruangsak-Torrissen, K.; Rustad, A.; Sunde, J.; Eiane, S.; Jensen, H.; Opstvedt, J.; Nygard, E.; Samuelsen, T.; Mundheim, H.; Luzzana, U.; Venturini, G. In vitro digestibility based on fish crude enzyme extract for prediction of feed quality in growth trials. J. Sci. Food Agric. 2002, 82, 644-654.

(12) Romarheim, O. H.; Skrede, A.; Penn, M.; Mydland, L. T.; Krogdahl, A.; Storebakken, T. Lipid digestibility, bile drainage and development of morphological intestinal changes in rainbow trout (Oncorhynchus mykiss) fed diets containing defatted soybean meal. Aquaculture 2008, 274, 329-338.

(13) Fountoulaki, E.; Alexis, M. N.; Nengas, I.; Venou, B. Effect of diet composition on nutrient digestibility and digestive enzyme levels of gilthead sea bream (Sparus aurata L.). Aquacult. Res. 2005, 36, $1243-1251$.

(14) Krogdahl, A.; Sundby, A.; Olli, J. J. Atlantic salmon (Salmo salar) and rainbow trout (Oncorhynchus mykiss) digest and metabolize nutrients differently. Effects of water salinity and dietary starch level. Aquaculture 2004, 229, 335-360.

(15) Pavasovic, A.; Anderson, A. J.; Mather, P. B.; Richardson, N. A. Effect of a variety of animal, plant and single cell-based feed ingredients on diet digestibility and digestive enzyme activity in redclaw crayfish, Cherax quadricarinatus (Von Martens 1868). Aquaculture 2007, 272, 564-572.

(16) Martin, S. A.; Vilhelmsson, O.; Medale, F.; Watt, P.; Kaushik, S.; Houlihan, D. F. Proteomic sensitivity to dietary manipulations in rainbow trout. Biochim. Biophys. Acta 2003, 1651, 17-29.

(17) Kolditz, C. I.; Paboeuf, G.; Borthaire, M.; Esquerre, D.; SanCristobal, M.; Lefevre, F.; Medale, F. Changes induced by dietary energy intake and divergent selection for muscle fat content in rainbow trout (Oncorhynchus mykiss), assessed by transcriptome and proteome analysis of the liver. BMC Genomics 2008, 9, 506.

(18) Rodrigues, P. M.; Silva, T. S.; Dias, J.; Jessen, F. Proteomics in aquaculture: applications and trends. J. Proteomics 2012, http://dx.doi. org/10.1016/j.bbr.2011.03.031

(19) Bligh, E. G.; Dyer, W. J. A rapid method of total lipid extraction and purification. Can. J. Biochem. Physiol. 1959, 37, 911-917.

(20) Lowry, O. H.; Rosebrough, N. J.; Farr, A. L.; Randall, R. J. Protein measurement with the Folin phenol reagent. J. Biol. Chem. 1951, 193, 265-275.

(21) Wulff, T.; Hoffmann, E. K.; Roepstorff, P.; Jessen, F. Comparison of two anoxia models in rainbow trout cells by a 2-DE and MS/MS-based proteome approach. Proteomics 2008, 8, 20352044.

(22) Forne, I.; Abian, J.; Cerda, J. Fish proteome analysis: model organisms and non-sequenced species. Proteomics 2009, 10, 858-872.

(23) Rabilloud, T.; Charmont, S. Detection of proteins on twodimensional electrophoresis gels. In Proteome Research: Two-Dimensional Gel Electrophoresis and Identification Methods; Rabilloud, T., Ed.; Springer-Verlag: Berlin, Germany, 2000; pp 107-126.

(24) Jensen, K. N.; Jessen, F.; Jorgensen, B. M. Multivariate data analysis of two-dimensional gel electrophoresis protein patterns from few samples. J. Proteome Res. 2008, 7, 1288-1296.

(25) Martens, H.; Martens, M. Modified Jack-knife estimation of parameter uncertainty in bilinear modelling by partial least squares regression (PLSR). Food Qual. Pref. 2000, 11, 5-16.

(26) Barrows, F. T.; Gaylord, T. G.; Stone, D. A. J.; Smith, C. E. Effect of protein source and nutrient density on growth efficiency, histology and plasma amino acid concentration of rainbow trout (Oncorhynchus mykiss Walbaum). Aquacult. Res. 2007, 38, 1747-1758.

(27) Belanger, F.; Blier, P. U.; Dutil, J. D. Digestive capacity and compensatory growth in Atlantic cod (Gadus morhua). Fish Physiol. Biochem. 2002, 26, 121-128.

(28) Chaiyapechara, S.; Casten, M. T.; Hardy, R. W.; Dong, F. M. Fish performance, fillet characteristics, and health assessment index of rainbow trout (Oncorhynchus mykiss) fed diets containing adequate and high concentrations of lipid and vitamin E. Aquaculture 2003, 219, 715-738.

(29) Furne, M.; Garcia-Gallego, M.; Hidalgo, M. C.; Morales, A. E.; Domezain, A.; Domezain, J.; Sanz, A. Effect of starvation and refeeding 
on digestive enzyme activities in sturgeon (Acipenser naccarii) and trout (Oncorhynchus mykiss). Comp. Biochem. Physiol. A-Mol. Integr. Physiol. 2008, 149, 420-425.

(30) Krogdahl, A.; Bakke-McKellep, A. M. Fasting and refeeding cause rapid changes in intestinal tissue mass and digestive enzyme capacities of Atlantic salmon (Salmo salar L.). Comp. Biochem. Physiol. A-Mol. Integr. Physiol. 2005, 141, 450-460.

(31) Furne, M.; Hidalgo, M. C.; Lopez, A.; Garcia-Gallego, M.; Morales, A. E.; Domezain, A.; Domezaine, J.; Sanz, A. Digestive enzyme activities in Adriatic sturgeon Acipenser naccarii and rainbow trout Oncorhynchus mykiss. A comparative study. Aquaculture 2005, 250, 391-398

(32) Mambrini, M.; Roem, A. J.; Carvedi, J. P.; Lalles, J. P.; Kaushik, S. J. Effects of replacing fish meal with soy protein concentrate and of DL-methionine supplementation in high-energy, extruded diets on the growth and nutrient utilization of rainbow trout, Oncorhynchus mykiss. J. Anim. Sci. 1999, 77, 2990-2999.

(33) Haard, N. F.; Dimes, L. E.; Arndt, R. E.; Dong, F. M. Estimation of protein digestibility. 4. Digestive proteinases from the pyloric caeca of coho salmon (Oncorhynchus kisutch) fed diets containing soybean meal. Comp. Biochem. Physiol. B-Biochem. Mol. Biol. 1996, 115, 533540.

(34) Rawlings, N. D.; Barrett, A. J., Evolutionary Families of Metallopeptidases; Academic Press: San Diego, CA, 1995; pp 183-228.

(35) Douglas, S. E.; Gallant, J. W.; Bullerwell, C. E. Molecular investigation of aminopeptidase $\mathrm{N}$ expression in the winter flounder, Pleuronectes americanus. J. Appl. Ichthyol. (Z. Angew. Ichthyol.) 1999, 15, $80-86$.

(36) Eliason, E. J.; Higgs, D. A.; Farrell, A. P. Postprandial gastrointestinal blood flow, oxygen consumption and heart rate in rainbow trout (Oncorhynchus mykiss). Comp. Biochem. Physiol. A-Mol. Integr. Physiol. 2008, 149, 380-388.

(37) Thorarensen, H.; Farrell, A. P. Postprandial intestinal blood flow, metabolic rates, and exercise in Chinook salmon (Oncorhynchus tshawytscha). Physiol. Biochem. Zool. 2006, 79, 688-694.

(38) Seth, H.; Sandblom, E.; Axelsson, M. Nutrient-induced gastrointestinal hyperemia and specific dynamic action in rainbow trout (Oncorhynchus mykiss)-importance of proteins and lipids. Am. J. Physiol. Regul. Integr. Comp. Physiol. 2009, 296, R345-R352.

(39) Maillou, J.; Nimmo, I. A. Albumin-like proteins in the serum of rainbow-trout (Salmo gairdneri). Comp. Biochem. Physiol. B-Biochem. Mol. Biol. 1993, 104, 387-393.

(40) Axelsson, M.; Fritsche, R. Effects of exercise, hypoxia and feeding on the gastrointestinal blood flow in the Atlantic cod Gadus morhua. J. Exp. Biol. 1991, 158, 181-198.

(41) Axelsson, M.; Thorarensen, H.; Nilsson, S.; Farrell, A. P. Gastrointestinal blood flow in the red Irish lord, Hemilepidotus hemilepidotus: long-term effects of feeding and adrenergic control. J. Comp. Physiol. B-Biochem. Syst. Environ. Physiol. 2000, 170, 145-152.

(42) Her, G. M.; Chiang, C. C.; Wu, J. L. Zebrafish intestinal fatty acid binding protein (I-FABP) gene promoter drives gut-specific expression in stable transgenic fish. Genesis 2004, 38, 26-31.

(43) Besnard, P.; Niot, I.; Poirier, H.; Clement, L.; Bernard, A. New insights into the fatty acid-binding protein (FABP) family in the small intestine. Mol. Cell. Biochem. 2002, 239, 139-147. 